\title{
ANALISA PENDAPATAN MANISAN KULIT SEMANGKA SEBAGAI UPAYA PENINGKATAN NILAI TAMBAH LIMBAH KULIT SEMANGKA
}

\author{
Sukarno \\ Email : dosen01565@ unpam.ac.id \\ Prodi Akuntansi D3/Fakutas Ekonomi/Universitas Pamulang \\ J1.Surya Kencana No.1, Tangerang Selatan \\ Imam Sofii \\ Email : imam_mpd@yahoo.co.id \\ Prodi Akuntansi D3/Fakutas Ekonomi/Universitas Pamulang \\ Jl.Surya Kencana No.1, Tangerang Selatan \\ Uswatun Chasanah \\ Email : dosen02021@unpam.ac.id \\ Prodi Akuntansi D3/Fakutas Ekonomi/Universitas Pamulang \\ Jl.Surya Kencana No.1, Tangerang Selatan
}

\begin{abstract}
ABSTRAK
Semangka mempunyai nama Latin Citrullus lanatus, masuk dalam suku Cucurbitaceae yang merupakan tanaman rambat yang cocok ditanam di daerah tropis dan subtropis. Namun untuk kulit semangka sering dibung begitu saja, padahal kulit semangka dapat diolah menjadi beragam jenis makanan atau camilan, misalnya manisan atau selai. Tujuan penelitian adalah untuk menguraikan estimasi pendapatan usaha pengolahan kulit semangka menjadi produk manisan kulit semangka sebagai upaya peningkatan nilai tambah limbah buah semangka. Penelitian dimulai dari analisis kandungan gizi pada kulit semangka hingga pembuatan produk manisan kulit semangka sampai pada pengumpulan data- data yang mendukung dalam analisa pendapatan usaha manisan kulit semangka. Jenis data yang digunakan dalam penelitian ini adalah data primer dan data sekunder. Data primer diperoleh melalui pengamatan dan praktek langsung pengolahan manisan kulit semangka dan wawancara untuk melengkapi informasi tentang objek penelitian. Dan data sekunder diperoleh dari instansi pemerintah, buku, internet dan studi literatur yang terkait dengan penelitian. Analisa pendapatan suatu usaha merupakan hasil selisih antara penjualan dengan total pengeluaran usaha.Kemudian dilakukan analisa tingkat kelayakan inovasi dengan analisis $\mathrm{R} / \mathrm{C}$ rasio, jika $\mathrm{R} / \mathrm{C} 1$ layak untuk diterapkan, jika $\mathrm{R} / \mathrm{C}<1$ inovasi tersebut tidak layak untuk diterapkan sebagai upaya peningkatan nilai tambah limbah kulit semangka. Berdasarkan hasilo uji diperoleh hasil bahwa usaha pembuatan manisan semangka ini layak untuk dilakukan karena analisis rasio $\mathrm{R} / \mathrm{C}$ menunjukkan 5,7 atau $R / C>1$.
\end{abstract}

Kata Kunci: Analisa Pendapatan, Kulit Semangka, Manisan

\section{ABSTRACT}

Watermelon has the Latin name Citrullus lanatus, included in the Cucurbitaceae family, a vine suitable for planting in tropical and subtropical areas. However, watermelon skin is often wrapped just like that, even though watermelon skin can be processed into various types of food or snacks, such as sweets or jam. The research objective was to describe the estimated income from the watermelon skin processing business to become candied watermelon skin products to increase watermelon waste's added 
value. The research started from analyzing the nutritional content of watermelon skin to the manufacture of candied watermelon skin products to the collection of supporting data in analyzing the income of the watermelon skin candied business. The types of data used in this study are primary data and secondary data. Preliminary data were obtained through direct observation and practice of processing watermelon skin sweets and interviews to complete information about the research object. And secondary data obtained from government agencies, books, the internet, and literature studies related to research. Analysis of a business's income is the result of the difference between sales and total business expenses. Then an analysis of the feasibility of innovation is carried out with an $\mathrm{R} / \mathrm{C}$ ratio analysis if $R$ / $C 1$ is feasible to apply if $R / C<1$, the invention is not possible to be implemented as an effort an increase in the added value of waste watermelon skin. Based on the test results, it was found that the business of making candied watermelon was feasible because the $R$ / $C$ ratio analysis showed 5.7 or $\mathbf{R} / \mathbf{C}>\mathbf{1}$.

Keywords: Income Analysis, Watermelon Skin, Sweets

\section{PENDAHULUAN}

Upaya meningkatkan pendapatan perlu didukung oleh pemerintah sebab pemerintah mempunyai peran yang paling penting karena mempunyai kewenangan dalam pengambilan kebijakan tingkat mikro dan makro, kebijakan-kebijakan yang diambil diharapkan mengarah pada komoditas-komoditas yang mempunyai keunggulan supaya kebijakan yang diambil lebih efektif dan terarah (Hikmawati, 2018). Sektor pertanian seharusnya menjadi skala prioritas pembangunan pemerintah sebab sektor pertanian dapat menjadi pendukung yang tangguh atas lajunya sektor industri dalam pembangunan, dan $80 \%$ penduduk indonesia bermukim di daerah pedesaan di mana sebagian besar berusaha di sektor pertanian dan 58,73\% dari jumlah rumah tangga nasional bergerak dalam kegiatan sektor pertanian (Saipal, Surullah, \& Mustafa, 2019).

Penelitian (Widowati, R., M. Rizal., 2015) melaporkan bahwa terjadi peningkatan pendapatan petani melalui pengolahan hasil keripik jamur tiram dan manisan jamur tiram yang ditunjukan dengan nilai R/C rasio yang lebih besar dari 1 untuk setiap komoditi yang diolah, di mana nilai $\mathrm{R} / \mathrm{C}$ rasio pengolahan keripik jamur tiram 1,98 dan manisan jamur tiram 1,53. Sedangkan penelitian (Novelina, 2010) menyatakan pembuatan manisan tempe dapat meningkatkan kesukaan masyarakat terhadap tempe dan dapat menjadi kegiatan pada industri rumah tangga atau menengah untuk dijadikan mata pencaharian dalam rangka meningkatkan penghasilan. Secara khusus dapat meningkatkan pendapatan pemilik industri tempe dengan semakin meningkatnya kesukaan masyarakat terhadap produk olahan tempe seperti manisan tempe. Penelitian (Darwis, Muslim, \& Askin, 2009) menguatkan bahwa tambahan penghasilan bagi petani ubi kayu dapat dilaksanakan dengan pengolahan ubi kayu menjadi tapioka. Dalam satu kilogram ubi kayu basah dapat 
menghasilkan pati tapioka sebesar 30\% dan biaya yang dikeluarkan untuk proses pembuatan tapioka sebesar Rp 125. Apabila petani menjual dalam bentuk tapioka, maka petani akan mendapatkan tambahan penghasilan sebesar Rp 35/kg.

Buah semangka merupakan buah yang banyak mengandung air dan vitamin, dimana air dibutuhkan untuk menghilangkan dehidrasi dan vitamin digunakan untuk menjaga kesehatan tubuh. Adapun kandungan buah semanka antara lainn air sebanyak 93,4g, protein $0,5 \mathrm{~g}$, karbohidrat 5,3g, lemak $0,1 \mathrm{~g}$, serat $0,2 \mathrm{~g}$, abu $0,7 \mathrm{~g}$, dan vitamin $(\mathrm{A}, \mathrm{B}$, dan C) dengan kandungan vitamin C sebesar $6 \mathrm{mg}$ per $100 \mathrm{~g}$ bahan (Gunawan, Studi, Universitas, \& Pengaraian, 2014). Dengan kandungan tersebut maka terdapat beberapa manfaat dari semangka adalah mencegah dehidrasi, melindungi fungsi saraf, menurunkan frekuensi serangan asma, menjaga kesehatan kulit dan rambut dan membantu menurunkan berat badan. Dari semua manfaat dan keberadaannya yang tidak dipengaruhi oleh musim maka buah semangka bisa didapatkan dimana dan kapan saja. Menurut Statistik pertanian Tahun 2017 maka komoditas semangka dihasilkan sebanyak 480.884 ton pada tahun 2015 dan hal ini mengalami penurunan $-16,54 \%$ dari tahun sebelumnya. Kualitas pengolahan kulit semangka juga dapat menjadi acuan dalam penelitian ini, karena karakteristik manisan kulit semangka instan terbaik diperoleh dari lama fermentasi 48 jam dan konsentrasi gula 65\% (Siregar, 2016).

Besarnya tingkat konsumsi semangka berbanding lurus dengan limbah yang dihasilkan yakni salah satunya adalah kulit semangka. Kulit semangka merupakan bagian buah semangka yang tidak bisa dikonsumsi. Bagian ini bisa dimanfaatkan atau diolah menjadi manisan kulit semangka. Menurut (Nusa et al., 2014) pengolahan kulit semangka menjadi manisan sebagai langkah dalam rangka meningkatkan nilai tambah serta diversifikasi produk olahan pangan jenis baru. Berdasarkan hasil penelitian yang telah dilakukan (Ismayanti, Bahri, \& Nurhaeni, 2013) kandungan antioksidan pada kulit buah semangka bulat dengan berat 1,4 kg dan volume $915 \mathrm{ml}$ diperoleh 214,369 ppm.

Hal ini tentu saja akan meningkatkan nilai tambah dari limbah buah semangka, yang biasanya kulit semangka hanya dibuang atau dijadikan pupuk organik bisa kita olah menjadi manisan kulit semangka. Oleh karena itu perlunya pengolahan limbah kulit semangka menjadi manisan buah, selain mengurangi jumlah sampah juga bisa meningkatkan nilai tambah yang pada akhirnya memberi tambahan pendapatan bagi keluarga. 


\section{METODE PENELITIAN}

\section{Tempat dan Waktu Penelitian}

Penelitian ini dilakukan di Universitas Pamulang, Kecamatan Pamulang Kota Tangerang Selatan Provinsi Banten dengan estimasi waktu bulan Maret - Juli 2020.

\section{Bahan dan Alat}

Bahan yang digunakan kulit semangka, gula pasir, pandan, citric acid dan air.

Sedangkan alat yang digunakan adalah kompor, panci, pisau, talenan dan ember.

Jenis data yang digunakan dalam penelitian ini adalah data primer dan data sekunder.

Data primer diperoleh melalui pengamatan dan praktek langsung pengolahan manisan kulit semangka. Selain itu, data primer berupa wawancara dapat dilakukan apabila diperlukan untuk melengkapi informasi tentang objek penelitian. Data sekunder diperoleh dari instansi pemerintah yang terkait seperti Dinas Pertanian dan Tanaman Pangan Kota Tangerang Selatan, buku, internet dan studi literatur yang terkait dengan penelitian.

\section{Hasil}

\section{HASIL DAN PEMBAHASAN}

\section{Pendapatan Usaha Pengolahan Kulit Semangka Menjadi Produk Manisan Sebagai}

\section{Upaya Peningkatan Nilai Tambah Limbah Buah Semangka}

Pendapatan adalah hasil selisih antara penjualan (sales) dengan total pengeluaran usahatani, sehingga dapat dijadikan keuntungan yang mudah sebagai input factor pada usaha berikutnya dan pengeluaran konsumsi rumah tangga (Pasaribu, 2012). Sementara pendapatan individu menurut Sukirno dalam (Firman, 2019) adalah pendapatan yang diperoleh seluruh rumahtangga dalam perekonomian dari pembayaran atas penggunaan faktor-faktor produksi yang dimilikinya dari sumber lain, dengan kata lain pendapatan yaitu jumlah penghasilan yang diperoleh oleh penduduk atas prestasi kerjanya dalam satu periode tertentu, baik yang diperoleh secara harian, secara mingguan, secara bulanan maupun secara tahunan.

\section{Tahapan Pengumpulan Data}

\section{a. Analisis Kandungan Gizi Kulit Semangka}

Analisis kandungan gizi dilakukan pada kulit semangka yang belum diolah menjadi manisan dan yang sesudah menjadi manisan. Analisis yang rencana akan dilakukan adalah uji proksimat berupa kadar air, kadar abu, protein, lemak, karbohidrat, dan energi. Analisis 
kandungan proksimat bertujuan sebagai data penunjang yang menjadi landasan bahwa manisan kulit semangka memiliki kandungan gizi yang lebih tinggi dibandingkan dengan kulit semangka yang belum dijadikan produk manisan. Hasil dari uji proximat masih belum keluar dari Laboratorium central Sucofindo di Bekasi. Bila tidak ada halangan maka hasil uji lab dari Sucofindo akan keluar pada tanggal 22 oktober 2020. Adapun bukti pengajuan uji laboratorium Sucofindo ditunjukkan pada order confirmation dibawah ini.

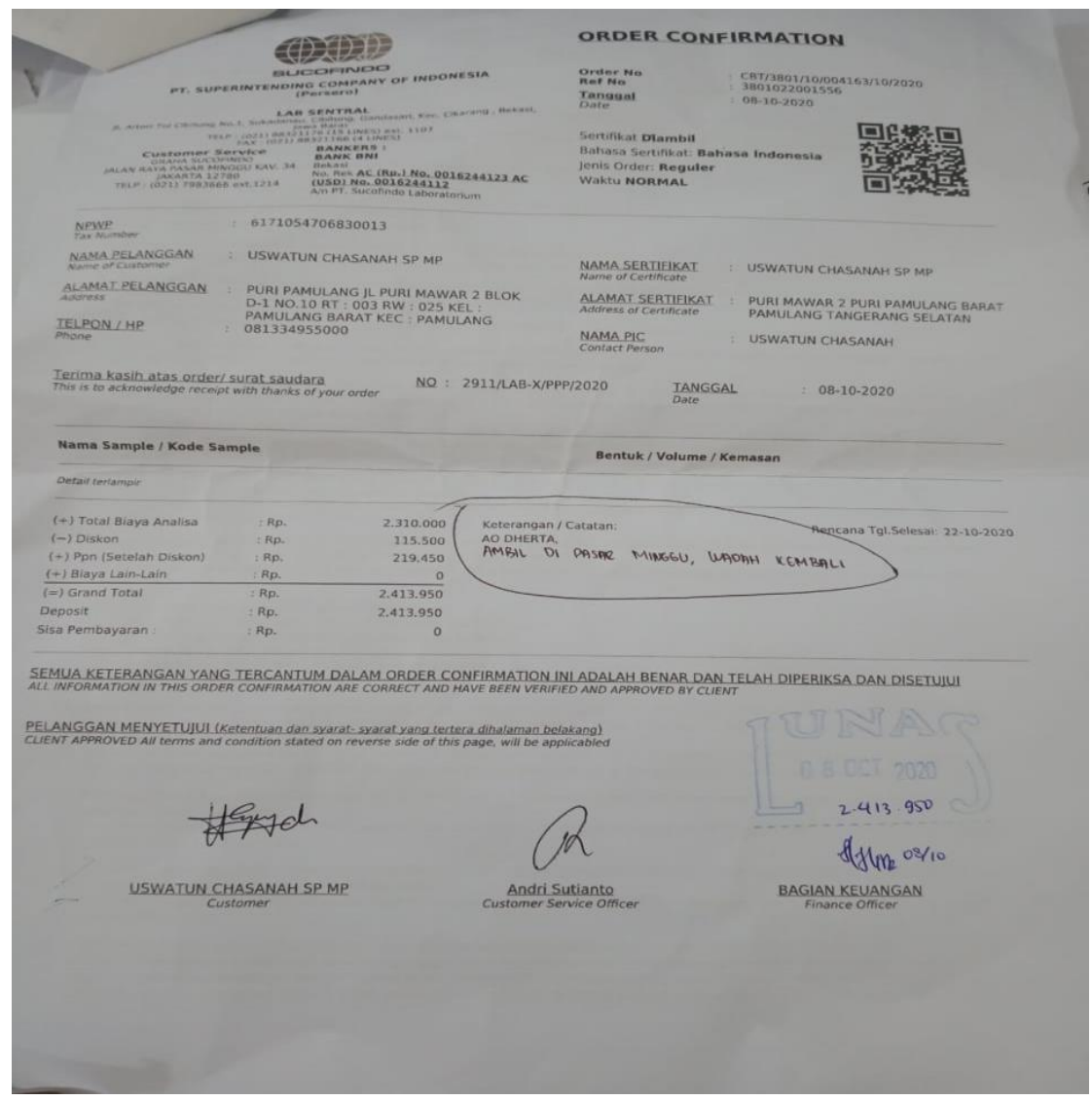

Gambar 1. Bukti Order Confirmation Sucofindo

\section{b. Pembuatan Manisan Kulit Semangka}

Proses pembuatan manisan yaitu : (1) Kupas bagian kulit semangka terluar (biasanya berwarna hijau); (2) Kulit semangka yang sudah terkumpul dipotong-potong sesuai selera; (3) Kulit semangka yang sudah dipotong-potong dimasukkan panci yang berisi air, gula dan citric acid; (4) setelah setelah mendidih dan mengental manisan didiamkan terlebih dahulu; (5) manisan yang sudah dingin siap dikemas dan dipasarkan. Pembuatan masisan sudah dilakukan dan sekarang masih menunggu keluarnya hasil Lab untuk uji proximat. Uji proximat dilakukan pada kulit semangka dan setelah kulit semangka diolah menjadi manisan. 


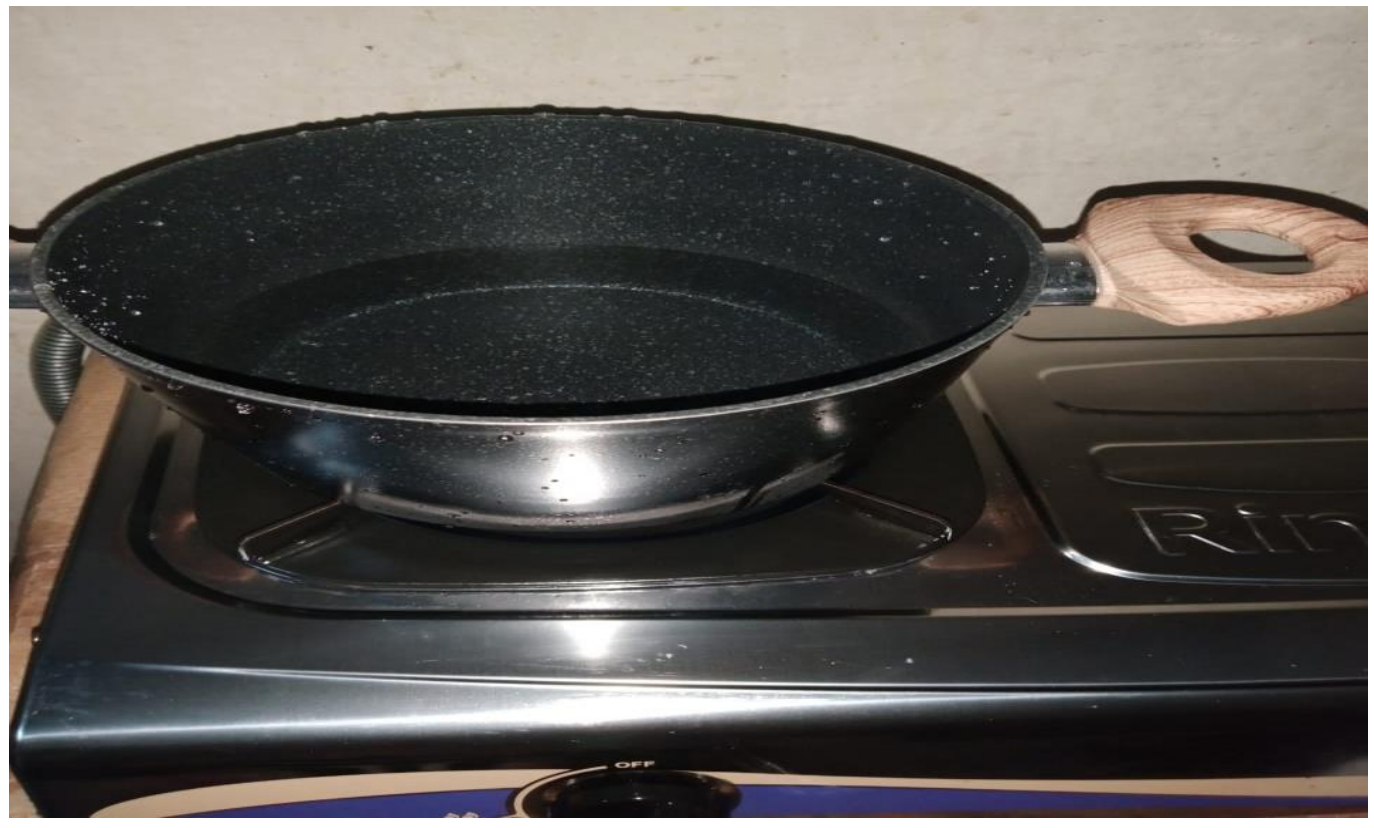

Gambar 2. Alat Pembuatan Manisan Kulit Semangka

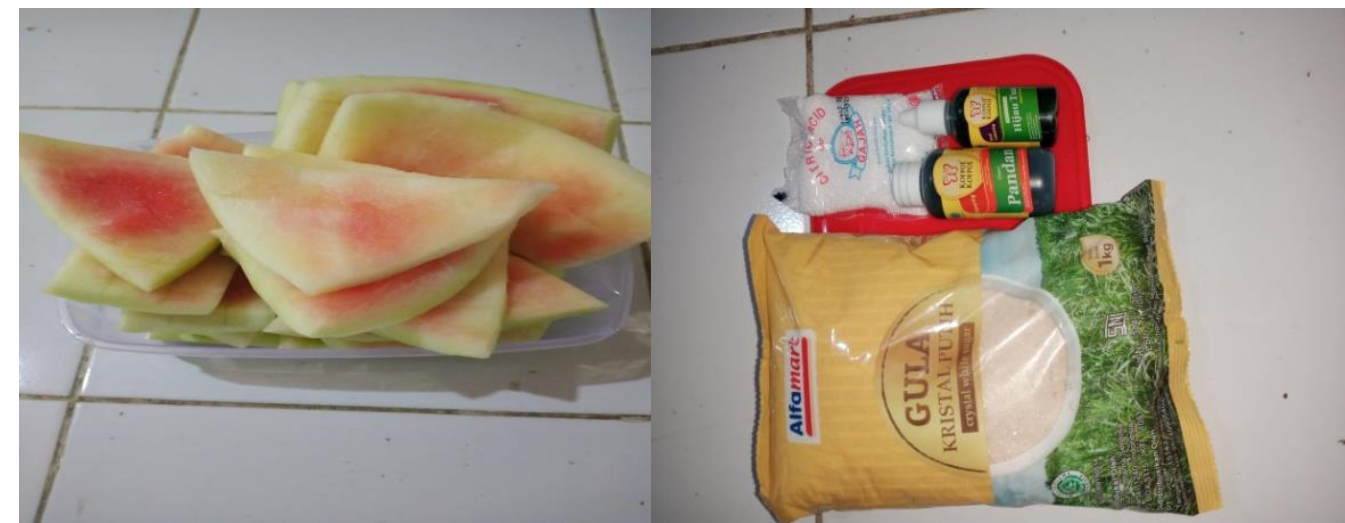

Gambar 3. Bahan-bahan Pembuatan Manisan Kulit Semangka

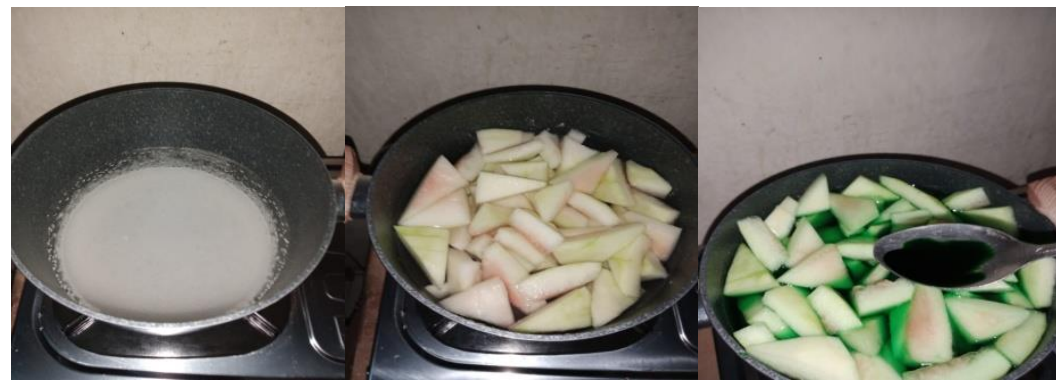

(1)
$(2)$

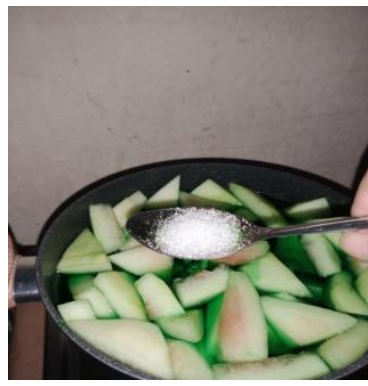

(4) 


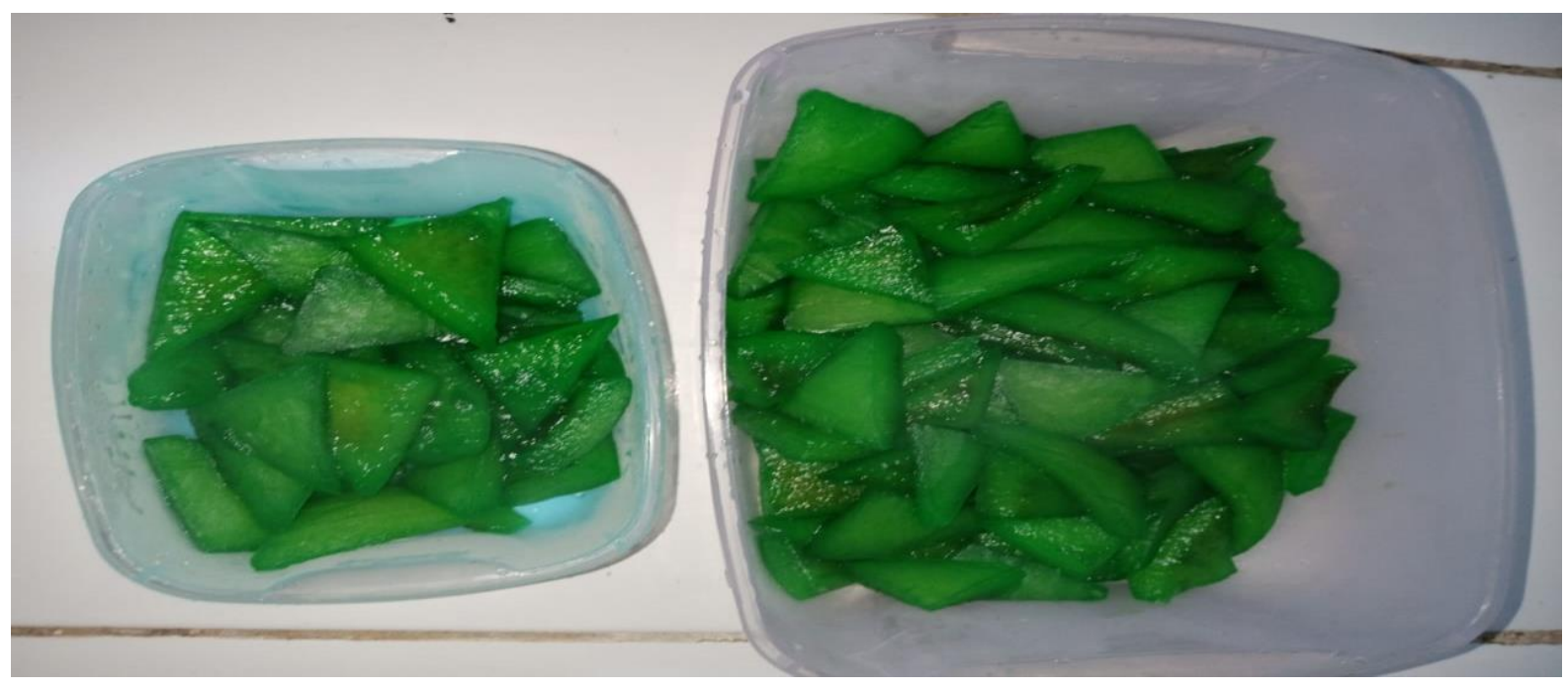

(5)

\section{Gambar 4. Pembuatan Manisan Kulit Semangka}

Cara pembuatan Manisan Kulit Semangka:

(1) Perebusan Air hingga mendidih kemudian ditambahkan gula pasir

(2) Kulit semangka dimasukkan dalam rebusan air gula

(3) Pemberian pewarna makanan dan pasta pandan

(4) Pemberian citric acid

(5) Manisan Kulit semangka sudah jadi

\section{c. Pengamatan}

Pengamatan dilakukan dengan menentukan bahan dan alat yang digunakan untuk usaha pembuatan manisan kulit semangka dari awal hingga akhir proses pembuatan. Sehingga dapat ditentukan estimasi harga jual yang dapat menghasilkan keuntungan usaha manisan kulit semangka. Dari hasil penelitian didapatkan besaran biaya sebagai berikut:

Fixed Cost (biaya tetap) terdiri adalah kompor, panci, pisau, talenan, dan ember. Biaya yang dikeluarkan untuk pembelian alat akan terlihat pada tabel 1.

Tabel 1. Fixed Cost Manisan Kulit Semangka

\begin{tabular}{|l|l|r|}
\hline No & \multicolumn{1}{|c|}{ Nama Alat } & Harga \\
\hline 1 & kompor + Selang paket & 459.895 \\
\hline 2 & panci & 257.500 \\
\hline 3 & pisau & 119.995 \\
\hline 4 & talenan & 69.995 \\
\hline 5 & ember & 52.995 \\
\hline \multicolumn{2}{|c|}{ Total } \\
\multicolumn{2}{|c|}{ Sumber : Data primer diolah, 2020.380 } \\
\hline \multicolumn{2}{|c}{}
\end{tabular}

Dari biaya tetap yang didapatkan diatas maka akan digunakan untuk memperoleh 
besaran biaya penyusutan. Biaya penyusutan diperoleh dari harga yang diperoleh umur ekonomis, sehingga didapatkan nilai seperti pada Tabel berikut .

\section{Tabel 2. Biaya Penyusutan Manisan Kulit Semangka}

\begin{tabular}{|l|l|r|}
\hline No & \multicolumn{1}{|c|}{ Uraian } & \multicolumn{2}{|c|}{ Harga } \\
\hline 1 & Fixed cost (Rp) & $\mathbf{9 6 0 . 3 8 0}$ \\
\hline 2 & Umur ekonomis (th) & $\mathbf{1 0}$ \\
\hline & Biaya Penyusutan/th & $\mathbf{9 6 . 0 3 8}$ \\
\hline
\end{tabular}

Sumber : Data Primer diolah, 2020.

Berdasarkan biaya penyusutan diatas maka didapatkan biaya tetap tiap bulan sebesar $\mathrm{Rp}$. 96.038 : 12 bulan = Rp. 8.003/bulan.

Adapun Variable cost (Biaya tidak tetap) yang digunakan dalam pembuatan manisan kulit semangka terdiri dari kulit semangka, gula pasir, pandan, citric acid dan air. Rincian penggunaan dana adalah sebagai berikut.

Tabel 3. Variable Cost Manisan Kulit Semangka

\begin{tabular}{|l|l|r|}
\hline No & \multicolumn{1}{|c|}{ Nama Bahan } & \multicolumn{2}{|c|}{ Harga } \\
\hline 1 & Kulit Semangka & 10.000 \\
\hline 2 & Gula Pasir & 12.400 \\
\hline 3 & Pandan & 2.000 \\
\hline 4 & Citric Acid & 500 \\
\hline 5 & Air & 1.000 \\
\hline 6 & Pewarna Makanan & 1.000 \\
\hline & Total & $\mathbf{2 6 . 9 0 0}$ \\
\hline
\end{tabular}

Sumber : Data primer diolah, 2020.

Variable cost diatas merupakan pembuatan manisan kulit semangka dengan menggunakan kulit semangka sebanyak $2 \mathrm{Kg}$. Dari Penelitian yang sudah dilakukan maka didapatkan biaya tetap sebesar Rp. 8.003 dan biaya tidak tetap sebesar Rp. 26.900. Dari data tersebut bisa digunakan untuk mengetahui total biaya dalam pembuatan maisan kulit semangka. Total cost akan ditunjukkan pada Tabel 4 berikut ini.

Tabel 4. Total Cost Manisan Kulit Semangka

\begin{tabular}{|l|l|r|}
\hline No & \multicolumn{1}{|c|}{ Biaya (Cost) } & Harga \\
\hline 1 & Fixed Cost & $\mathbf{8 . 0 0 3}$ \\
\hline 2 & Variabel Cost & $\mathbf{2 6 . 9 0 0}$ \\
\hline & Total Cost & $\mathbf{3 4 . 9 0 3}$ \\
\hline
\end{tabular}

Sumber : Data Primer diolah, 2020.

Berdasarkan Total Cost diatas merupakan total cost pada satu kali pembuatan manisan kulit semangka. Bila manisan dibuat setiap hari maka akan didapatkan biaya total sebesar Rp. 34.903 x 30 hari = Rp. 418.836/bulan

Besarnya penerimaan yang diperoleh petani dipengaruhi oleh besarnya jumlah produksi dan harga jual yang dihasilkan. Dari hasil penelitian didapatkan informasi bahwa 
harga (P) Rp. 40.000/Kg dengan kuantitas (Q) sebanyak 2 Kg tiap kali membuat manisan. Bila sehari $2 \mathrm{Kg}$ maka dalam satu bulan didapatkan manisan sebanyak $60 \mathrm{Kg}$. Total Revenue (TR) dari pembuatan manisan dapat dilihat pada tabel 5.

Tabel 5. Total Revenue Manisan Kulit Semangka

\begin{tabular}{|l|l|r|}
\hline No & \multicolumn{1}{|c|}{ Uraian } & Jumlah \\
\hline 1 & Harga $(\mathrm{Rp})$ & $\mathbf{4 0 . 0 0 0}$ \\
\hline 2 & Kuantitas $(\mathrm{Kg})$ & $\mathbf{6 0}$ \\
\hline & Total Revenue & $\mathbf{2 . 4 0 0 . 0 0 0}$ \\
\hline
\end{tabular}

Sumber : Data primer diolah, 2020.

Dari tabel 5 didapatkan informasi bahwa total penerimaan yang diperoleh adalah sebesar Rp. 2.400.000/ bulan dengan diasumsikan produksi tiap hari $2 \mathrm{Kg}$.

Sedangkan untuk menghitung besarnya pendapatan dari pembuatan manisan kulit semangka adalah sebagai berikut :

$$
\boldsymbol{\pi}=\mathbf{T R}-\mathbf{T C}
$$

$\pi=$ Rp. $2.400 .000-$ Rp. $418.836=$ Rp. 1.981 .164

Selanjutnya analisa tingkat kelayakan inovasi digunakan analisis $\mathrm{R} / \mathrm{C}$ rasio, jika $\mathrm{R} / \mathrm{C}$ $>1$ layak untuk diterapkan, jika $\mathrm{R} / \mathrm{C}<1$ inovasi tersebut tidak layak untuk diterapkan. Berdasarkan hasil penellitian didapatkan informasi bahwa TR $=$ Rp. 2.400 .000 dan TC $=$ Rp. 418.836 Jadi didapatkan $\mathrm{R} / \mathrm{C}$ rasio sebesar :

\section{$\mathrm{R} / \mathrm{C}$ Rasio $=\mathrm{TR} / \mathrm{TC}$}

Rp. $2.400 .000 /$ Rp. $418.836=5,7$

Dari nilai R/C rasio sebesar 5,7 maka usaha pembuatan manisan kulit semangka layak dilakukan.

\section{KESIMPULAN}

Berdasarkan hasil uji kelayakan antara Revenue/Cost maka diperoleh hasil bahwa pembuatan manisan semangka ini layak untuk dijadikan sebagai usaha alternatif dalam rangka memanfaatkan limbah kulit semangka yang selama ini kurang mendapat perhatian karena masyarakat cenderung hanya memanfaatkan daging semangkanya saja. Padahal jika diolah dengan baik akan mendatangkan nilai tambah yang cukup menjanjikan bagi keluarga.

\section{DAFTAR PUSTAKA}

Darwis, V., Muslim, C., \& Askin, A. (2009). USAHATANI DAN PEMASARAN UBI KAYU SERTA TEKNOLOGI PENGOLAHAN TAPIOKA DI KABUPATEN PATI PROVINSI JAWA TENGAH Farming and Marketing of Cassava and Tapioca 
Processing Technology in Pati Regency, Central Java Province. Seminar Nasional Peningkatan Daya Saing Agribisnis Berorientasi Kesejahteraan Petan, (Bogor).

Firman, H. (2019). Faktor - Faktor Yang Berpengaruh Terhadap Pendapatan Petani Rumput Laut Di Desa Tirowali Kecamatan Ponrang. Jurnal Ekonomi Pembangunan STIE Muhammadiyah Palopo, 5(1), 14-22. https://doi.org/10.35906/jep01.v5i1.335

Gunawan, I., Studi, P., Universitas, A., \& Pengaraian, P. (2014). ANALISIS PENDAPATAN USAHATANI SEMANGKA (Citrullus Vulgaris) DI DESA RAMBAH MUDA KECAMATAN RAMBAH HILIR KABUPATEN ROKAN HULU. Jurnal Sungkai, https://doi.org/https://doi.org/10.30606/js.v2i1.469

Hikmawati, H. (2018). Pengaruh Luas Lahan, Modal Dan Tenaga Kerja Terhadap Pendapatan Petani Tambak Udang Di Desa Tamuku Kecamatan Bone-Bone Kabupaten Luwu Utara. Jurnal Ekonomi Pembangunan STIE Muhammadiyah Palopo, 4(1), 1-12. https://doi.org/10.35906/jep01.v4i1.290

Ismayanti, Bahri, S., \& Nurhaeni. (2013). KAJIAN KADAR FENOLAT DAN AKTIVITAS ANTIOSIDAN JUS KULIT BUAH SEMANGKA (Citrullus Lanatus). Jurnal of Natural Science.

Novelina, D. S. (2010). MENINGKATKAN NILAI TAMBAH PRODUK TEMPE DENGAN DIVERSIFIKASI PRODUK MENJADI NUGGET. Warta Pengabdian Andalas, 16(25), 179 - 187.

Nusa, M. I., Fuadi, M., \& Sanjaya, S. (2014). Studi Pembuatan Manisan Kering Kulit Buah Semangka (Citrullus Lanatus). Agrium.

Pasaribu, A. M. (2012). Kewirausahaan Berbasis Agribisnis. Yogyakarta: CV. Andi Offset.

Saipal, M., Surullah, M., \& Mustafa, S. W. (2019). Faktor-Faktor Yang Mempengaruhi Pendapatan Petani Tambak Ikan Bandeng Di Desa Salekoe Kecamatan Malangke Kabupaten Luwu Utara. Jurnal Ekonomi Pembangunan STIE Muhammadiyah Palopo, 5(1), 31-41. https://doi.org/10.35906/jep01.v5i1.338

Siregar, G. A. T. (2016). Pengaruh Lama Fermentasi dan Konsentrasi Gula Terhadap Mutu Manisan Kulit Semangka. Jurnal Ilmu Dan Teknologi Pangan, 4(2).

Widodo, S. (2017). KANDUNGAN GIZI SELAI KULIT SEMANGKA LEMBARAN DENGAN PENAMBAHAN JELLI. Http://Eprints.Unm.Ac.Id/.

Widowati, R., M. Rizal., D. N. P. (2015). Teknologi pengolahan hasil jamur tiram serta analisis usaha taninya di Kota Balikpapan, Provinsi Kalimantan Timur Processing technology and farming system analysis of oyster mushrooms in Balikpapan City ,. PROS SEM NAS MASY BIODIV INDON, 1(April), 337-342. https://doi.org/10.13057/psnmbi/m010228 